\title{
An Appraisal of Arsenic and Pesticide Toxicity for Economically Terminal People: a Snap Shot of North-Western Part of Bangladesh
}

\author{
S. M. M. Alam ${ }^{1 *}$, M. N. Farha' ${ }^{2}$ A. K. B. Zaman ${ }^{3}$ \\ ${ }^{1}$ Faculty of Science, University of Rajshahi, Rajshahi 6205, Bangladesh \\ ${ }^{2}$ Rajshahi University of Engineering and Technology, Rajshahi, Bangladesh \\ ${ }^{3}$ Barind Medical College, Rajshahi, Bangladesh
}

Received 30 May 2015, accepted in final revised form 18 August 2015

\begin{abstract}
The aims of this study were to detect the levels of arsenic (As) and selected organophosphorus pesticides (OPPs) in the drinking water and the water from surface sources, respectively for a small section of poor people of the country Bangladesh, and to relate the levels of these offensive chemicals with their acute physical ailments. Mean levels of As in drinking water from tube wells are found $0.10 \pm 0.01 \mathrm{mg} \mathrm{L}^{-1}$, which are nearly ten times higher than the maximum tolerable limits for humans. Correlation studies suggest that higher level of As is significantly correlated with total dissolved solids (TDS) and with few more water quality parameters investigated here. Similar to that, residues of selected OPPs in surface water of the area are also found several fold higher $\left(0.24-0.48 \mu \mathrm{g} \mathrm{L}^{-1}\right)$ than the expected levels, and if the suspended solids of that water are considered then the residue levels would have been further higher. This study has a merit for its findings regarding As toxicity as well as possible OPPs contamination in the investigated area, and suffering of the people from both exposures in relation with their poor economical power is addressed.
\end{abstract}

Keywords: Arsenic toxicity; Pesticides; Exposure; Social status.

(C) 2015 JSR Publications. ISSN: 2070-0237 (Print); 2070-0245 (Online). All rights reserved. doi: http://dx.doi.org/10.3329/jsr.v7i3.23540

J. Sci. Res. 7 (3), 159-165 (2015)

\section{Introduction}

In Bangladesh, arsenic (As) contamination of water in tube-wells was first reported in 1997 [1]. It can be found that tube-wells could be the prime sources for daily consumption of water in rural areas. Since then a sizeable number of works can be found on level of As in drinking waters and food chains in many regions of the country [2-5]. Moreover,

\footnotetext{
*orresponding author: smmalam@ru.ac.bd
} 
examination of more than thousand patients, residing in different villages of Bangladesh, where As concentrations in drinking water were ranged from 10 to 2,040 $\mu \mathrm{g} \mathrm{L}^{-1}$ were done, and almost one third of them were found to have skin related problems [6]. However, as to date small numbers of cases of skin cancer have started to appear, since the typical latency is more than 20 years after the beginning of exposure [7], the fact that even small number have been found but that provides some reassurances about the future incidence of skin cancer in the country. It is also assumed that apart from nonoccupational exposure, ingestion of As in food is the main route of As exposure [5]. However, in areas where concentrations of As in drinking water exceed $100 \mu \mathrm{g} \mathrm{L}^{-1}$ e.g., in many parts of Bangladesh, this source is significant and, in some cases, may even be the principle contributor to the daily intake of As.

Information about the quantity and the identity of all types of pesticides those have been using in this country is virtually unavailable [8-11]. One important issue can be noticed that many pesticides are being used or still being produced in this country are already banned and/or restricted under international agreements [12,13] e.g., DDT for instance [14-16]. On the other hand, statistical database called 'FAOSTAT' of Food and Agriculture organization (FAO) of United Nations (UN) can provide some reasonable data for the country [17] but conflicting information can be noticed from the above cited sources [8-11]. Analysis of certain pesticides revealed that toxic chemicals (e.g., organophosphates) have been known to cause cancer in exposed populations [18]. The exposure of selected pesticides in this country is also reported elsewhere [14,16]. These evidences are also upheld that the restricted pesticides DDT is still being used in the country and their residue levels in the environmental matrices are quite high compared to what it should be. It has been found that pesticide consumption in this country is in increasing order and the exposure level of pesticides (which is $0.02 \mathrm{mg} / \mathrm{kg} / \mathrm{day}$ ) is much more higher than the expected level (which is $0.005 \mathrm{mg} / \mathrm{Kg} /$ day) [14]. It is also indicated that $100 \%$ of exposed people were claiming about their skin problems followed by respiratory illness [14]. Eventually it is assumed that organophosphorus pesticides (OPPs) are extensively used in all sorts of agriculture for the control of various pests in our country. Therefore, the uncontrolled distribution of these compounds in various environmental compartments like surface water bodies which are sometimes a prime source of indirect human consumption in some agrarian villages, would be a great concern for public health.

This study is an attempt to find out the scenario regarding the contamination of As and selected OPPs in the drinking water and the water from surface sources for household uses of a particular area of the country. Therefore, an attempt is taken to develop a better understanding of the relationships between water quality, including its As and selected OPPs levels by measuring the key physical and chemical properties of those useable waters which are collected from their local tube wells and surface waters from nearby. Such studies are of critical importance to provide the scientific services for any kind of risk to be assessed. A short description about the areas and the methods adopted are described below but details can be found elsewhere [19]. 


\section{Experimental}

\subsection{Study area}

Study area is in the northwestern district of the country (Nawabganj District) which was selected on the basis of specific patient identified those having skin lesions caused by continuous As exposure from their drinking sources, if not then, agrochemicals those are being handled by them could be the cause of their skin related problems. However, this area is described as less As prone areas compared to the rest of the places of the country [1-3]. Selection steps taken in the study which is from the study areas to the potential patients are given in the following table (Table 1). Actual selection steps were taken in a reverse manner that means, at first, patients (termed as potential patients) were identified upon their arrival for seeking services at hospital outdoor. After that a link was established to trace their community with an intention to find more cases to encounter, that attempt produces number of new cases. In addition to that, tube wells and surface water sources were selected for chemical analysis of As and various related parameters to establish whether any correlation can be established between the levels of As and the selected OPPs with the rest chemical parameters in the waters of those two sources.

Table 1. Basic information of the study area and the order of selection steps taken.

\begin{tabular}{ccccc}
\hline Village & Union/Paurasava & Thana/Upazila & District & Population (000) \\
\hline Namosankarbati & Sadar Paurasava & Nawabganj & Nawabganj & ca. 4 \\
\hline \multicolumn{2}{c}{ Drinking water sources } & $\begin{array}{c}\text { No. of drinkers } \\
\text { interviewed }\end{array}$ & $\begin{array}{c}\text { No. of drinkers Investigated } \\
\text { (termed as potential patients) }\end{array}$ \\
\hline $\begin{array}{c}\text { Samples taken } \\
\text { from tube wells }\end{array}$ & $\begin{array}{c}\text { \% of tube wells } \\
\text { of the area }\end{array}$ & 70 & & 7 \\
\hline 20 & $<98$ & & & \\
\hline
\end{tabular}

\subsection{Chemicals, instruments and procedures}

Estimations of water quality parameters are adopted from standard methods [20,21], and estimation of As is followed by the method used in elsewhere [19]. Standard OPPs (three in this case, Diazinon, Quinalphos and Profenofos are selected on the basis of their interviews, although these common OPPs are being used in the areas but with different trade names) and necessary chemicals were analytical standards and purchased from Dr. Ehrenstorfers GmbH laboratory (Augsburg, Germany). Estimation of standard OPPs and OPPs from sample waters were performed by Capillary electrophoresis on a CE - L1 instrument (CE Resources Pte. Ltd. Singapore) with a UV-Visible detector (SPD - 10A VP) from Shimadzu (Kyoto, Japan) and the methods can be found elsewhere [22]. 


\section{Results and Discussions}

Mean and standard deviation (SD) of ten parameters from 20 tube wells are presented in the Table 2, and their correlation matrices (only with As) are presented in Table 3. In the last column of the Table 2, is the status mark of water quality according to the standard water quality indices for drinking water [20,21]. Level of As and its EC is deliberately detrimental for the purpose and in some occasion its alkalinity is too be an offensive issue. From significant correlation values (Table 3) it is found that levels of As are positively correlated with depth, EC, TDS and alkalinity but shows negative correlation with $\mathrm{pH}$. It is, therefore, assumed that arguably high levels of TDS could be the prime cause of these higher EC, alkalinity and their offensive level of As, as pointed out in some earlier occasions [6]. Notwithstanding, some important inferences about the quality of water of tube wells in the study area can be drawn from that statistical analysis. Estimation of As in water with high sensitivity (e.g., detection limit below $20 \mathrm{ppb}$ ) is difficult to attain when simple field-useable kits or simple spectrophotometric methods are used. For that purpose sophisticated tool like Atomic Absorption Spectrophotometer (AAS) is required which may not be available except in few laboratories across the country, and the use of that particular machine for routine analysis is downright expensive. Therefore, when drinking water receiving from underground sources of a particular areas, and if the simple water quality parameters like $\mathrm{pH}$, EC and alkalinity are found strongly correlated with its As concentration, then this relationship can be simply be used for assessing the level of As in continuous screening tests. Here, depth of the sources could be used as another guide for avoiding higher level of As in water, attributing that if fresh water can be harvested from shallow tube wells would be safer than water harvested from deeper wells.

Table 2. Selected parameters of waters from 20 tube wells of study area.

\begin{tabular}{lll}
\hline Parameters & Mean \pm SD & Status Mark \\
\hline Depth, ft & $144 \pm 12$ & $\sqrt{ }$ \\
$\mathrm{pH}$ & $7.3 \pm 0.5$ & $\sqrt{ }$ \\
Electrical Conductivity (EC), $\mu \mathrm{S}$ & $626 \pm 279$ & $\mathrm{X}$ \\
*Arsenic (As), mg L-1 & $0.10 \pm 0.01$ & $\mathrm{X}$ \\
Total Dissolved Solids (TDS), $\mathrm{mg} \mathrm{L}^{-1}$ & $359 \pm 156$ & $\sqrt{ }$ \\
Calcium (Ca), mg L & $71 \pm 25$ & $\sqrt{ }$ \\
Magnesium (Mg), mg L & $\sqrt{ }$ \\
Chloride (Cl-), mg L & $9 \pm 3$ & $\sqrt{ }$ \\
Total Hardness (TH), mg L & $30 \pm 21$ & $\sqrt{ }$ \\
Alkalinity, mg L & $215 \pm 69$ & $\mathrm{~S}$ \\
\hline
\end{tabular}

*The detection limit (DL) of the method used was $20 \mu \mathrm{g} \mathrm{\textrm {L } ^ { - 1 }}\left( \pm 10 \mu \mathrm{g} \mathrm{\textrm {L } ^ { - 1 }}\right)$, therefore As concentrations those were found less than $20 \mu \mathrm{g} \mathrm{L}{ }^{-1}$ are put here as $0.01 \mathrm{mg} \mathrm{L}^{-1} ; \sqrt{ }$, Totally Safe; X, Totally Unsafe; S, Some of them are Safe 
Table 3. Correlation matrix ( $t$-values) of all parameters investigated with As contents of waters from 20 tube wells of the study area.

\begin{tabular}{|c|c|c|c|c|c|c|c|c|c|}
\hline & $\begin{array}{l}\text { Depth, } \\
\mathrm{ft}\end{array}$ & $\mathrm{pH}$ & $\begin{array}{l}\text { EC, } \\
\mu S\end{array}$ & $\begin{array}{l}\text { TDS, } \\
\text { ppm }\end{array}$ & $\begin{array}{l}\text { Ca, } \\
\text { ppm }\end{array}$ & $\begin{array}{l}\text { Mg, } \\
\text { ppm }\end{array}$ & $\begin{array}{l}\mathrm{Cl}^{-1}, \\
\mathrm{ppm}\end{array}$ & $\begin{array}{l}\text { TH, } \\
\text { ppm }\end{array}$ & $\begin{array}{l}\text { Alkalinity, } \\
\text { ppm }\end{array}$ \\
\hline $\begin{array}{l}\text { As, } \\
\text { ppm }\end{array}$ & $0.694 * *$ & $-0.623^{* *}$ & $0.538^{*}$ & $0.454 *$ & 0.286 & 0.329 & 0.274 & 0.374 & $0.548^{*}$ \\
\hline
\end{tabular}

\subsection{Estimation of OPPs}

As OPPs are virtually absent in those tube wells, therefore, sources of surface water e.g., nearby ponds (adjacent to the farming lands as well as to their homestead) are selected for the estimation of residues of those OPPs. For this purpose, $100 \mathrm{~mL}$ of replicated surface water samples were collected, filtrated and were separated by the similar methods as stated earlier, and the results are given in Table 4.

Table 4. Analysis of three OPPs in surface water samples.

\begin{tabular}{lll}
\hline Analyte & Concentration, $\left(\mu \mathrm{g} \mathrm{mL}^{-1}\right)$ & $\mathrm{DL},\left(\mu \mathrm{g} \mathrm{mL}^{-1}\right)$ \\
\hline Diazinon & 0.48 & 0.15 \\
Quinalphos & 0.35 & 0.11 \\
Profenofos & 0.24 & 0.13 \\
\hline
\end{tabular}

These levels of pesticides if present in water, are quite questionable and certainly several times higher than the tolerable limits for humans and livestock [12,13]. These OPPs are quite hydrophobic, therefore, it is assumed that certain portions are being bound on suspended organic compounds present in the water, and upon filtration this portion is being discarded. Therefore, total OPPs present would be higher. In the interview, peoples have stated that their livestock regularly drink from this pond, therefore, the residue level of these OPPs in the food chains would be a serious concern for the people of the area. However, the levels of these selected OPPs in the adjacent surface waters are corroborative to the earlier studies [12,13], and are quite high and support the appraisal that this sort of sources for continuous exposure is common in the areas and can be a cause for their reported illness.

\section{Conclusion}

Level of some water quality parameters present in water of those tube wells under investigation were found questionable. However, the levels of As present in these waters were found most of the time many fold higher compared to the world standards. Therefore, people of these areas depending on those tube wells are still under exposure of nearly $1 \mathrm{mg}$ As in a day, and normal health conditions of these peoples are found vulnerable and possibly attributable by their poorly conditions. However, it is beyond our capacity to bar the people from drinking without providing them any safer alternatives. 
Similar to that, the levels of three OPPs in the surface water of the areas could be the source of their pesticides exposure that may aggravate their physical illness further, and it would be a formidable task for physicians to address their total ailments with logical implications by real causes. Most of the people were interviewed told us that they are farmers and they have frequent poor health symptoms possibly associated with acute pesticide poisoning such as skin rash, eye irritation etc., and admitted that they usually do not have the capacity to take any protective measures during the handling of pesticides.

The perception of this study is to address the issue that people of the study areas are suffering from poor health in many ways especially with skin related problems which may demonstrates their regular exposure to As and some OPPs present in their water resources. As poverty exists in these areas (sometimes in extreme) with the people under investigation by interviews which is related to their poor income, and being unable to bear the cost of proper medical services.

\section{Acknowledgment}

Part of this work was made possible through facilities provided by the Universiti Teknologi Malaysia (UTM), Malaysia.

\section{References}

1. A. W. Khan, J. Preventive Soc. Med. 16(1), 65 (1997).

2. S. A. Ahmad, D. Bandaranayake, A. W. Khan, S. A. Hadi, G. Uddin, and M. A. Halim, Int. J. Environ. Health Res. 7, 271 (1997). http://dx.doi.org/10.1080/09603129773724

3. B. K. Biswas, R. K. Dhar, G. Samanta, B. K. Mandal, D. Chakraborti, I. Faruk, K. S. Islam, M. M. Chowdhury, A. Islam, and S. Roy, Current Sci. 74(2), 134 (1998).

4. M. Deb, S. Roy, and S. M. I. Huq, Bang. J. Sci. Res. 25(1), 43 (2012). http://dx.doi.org/10.3329/bjsr.v25i1.13049

5. A. Ghosh, M. A. Awal, S. Majumder, M. H. Sikder, and D. R. Rao, Bang. J. Pharmacol. 7, 178 (2012).

6. Executive Summary of the Main Report of Phase I, Groundwater Studies of Arsenic Contamination in Bangladesh British Geological Survey for the Government of Bangladesh, Ministry of Local Government, Rural Development and Cooperatives, Department of Public Health Engineering, and Department of International Development, UK, 1999).

7. J. P. Buchet, D. Lison, M. Ruggeri, V. Foa, and G. Elia, Arch Toxicol, 70, 773 (1996). http://dx.doi.org/10.1007/s002040050339

8. BBS, Statistical Yearbook (Bangladesh Bureau of Statistics, Section Industry, 2010) Chapter $5,162$.

9. BBS, Statistical Yearbook (Bangladesh Bureau of Statistics, Section Industry, 2010) Chapter $5,167$.

10. BBS, Statistical Yearbook (Bangladesh Bureau of Statistics, Section Industry, 2010) Chapter 5, 171.

11. BBS, Statistical Yearbook (Bangladesh Bureau of Statistics, Section Foreign Trade, 2010) Chapter 8, 237.

12. C. Meisner, Report of Pesticide Hotspots in Bangladesh, Report to the Canadian International Development Agency (CIDA) (World Bank, Washington DC, 2004).

13. NOVIB, Pesticides Misuse in Bangladesh, The Pesticides News in the Pesticides Trust. (London U.K., 1993). 
14. M. H. Rahman and M. J. B. Alam, J. Civil Eng. CE 25(1), 97 (1997).

15. S. Dasgupta, C. Meisner, and M. Huq, World Bank Policy Research Working Paper, 3776 (2005).

16. M. N. H. Bhuiyan, H. R. Bhuiyan, M. Rahim, K. Ahmed, K.M. F. Haque, M. T. Hassan, and M. N. I. Bhuiyan, Bangladesh J. Pharmacol. 3, 114, (2008).

17. www.fao.org/statistics/en/....visited on June 2015.

18. S. H. Zahm, M. H. Ward, and A. Blair, "Pesticides and Cancer" in Occupational Medicine: State of the Art Reviews, Pesticides, M. Keifer (ed) (Hanley and Belfus, Inc. 1997), 12, pp. 269.

19. A. K. B. Zaman, Arsenic Toxicity in Human Body and Its Chemical and Histopathological Studies (Ph. D Thesis in University of Rajshahi, Bangladesh, 2013) pp. 120.

20. Hach Water Analysis Handbook, $2^{\text {nd }}$ Edition (Hach Company, Loveland, Co., 1992).

21. APHA. Standard Methods for the Examination of Water and Wastewater, $18^{\text {th }}$ Edition (American Public Health Association, Washington, DC, USA, 1992).

22. S. M. M. Alam, Separation of Organophosphorus Pesticides Using Micellar Electrokinetic Chromatography (Ph. D Thesis in Universiti Teknologi Malaysia, Malaysia, 2005) pp. 134. 